\title{
Organization and Startup of The Gambia's New Community-Based Medical Programme
}

\author{
José A. Chávez MD MS, Lázaro V. Suárez MD, Odalis del Rosario MD MS, Suiberto Hechavarría MD MS, Judith Quiñones MD MS
}

\begin{abstract}
The shortage of health professionals in developing countries and especially in their poorest regions imperils the vision of health for all. New training policies and strategies are needed urgently to address these shortages. The Gambia's new Community-Based Medical Programme is one such strategy.
\end{abstract}

KEYWORDS Medical education, access to health care, healthcare disparities, health manpower, rural health, developing countries, The Gambia

\section{INTRODUCTION}

The WHO report for 2006, Working Together for Health, highlights the global need for more medical personnel, estimating the worldwide shortage of doctors, nurses, midwives, and other health workers at over 4 million. The largest deficits are in poor countries, particularly in sub-Saharan Africa and Southeast Asia,[1] the lack of human capital constituting a critical problem for their public health systems. There is an urgent need to develop new training policies that educate health personnel at lower costs and within shorter timeframes, designed to retain qualified professionals in areas where they are most needed. These initiatives are even more vital where there is near total absence of such professionals to address the social and health needs of entire populations.

The Republic of The Gambia is the smallest country in continental Africa: located on Africa's west coast, its territory extends 472 $\mathrm{km}$ into the interior along both banks of the Gambia River, with a breadth of some $50 \mathrm{~km}$, in the shape of a thin wedge penetrating Senegal from the Atlantic Ocean.[2] It is also one of the poorest nations in the world, with a human development index ranking of 168 of 187 countries,[3] \$320 per capita income (in 2007 US dollars) and $61.2 \%$ living below the poverty line (the latter a 2003 figure). Today, The Gambia has a population of approximately 1.75 million inhabitants with a life expectancy of 60 years, estimated infant mortality rate of 78 per 1000 live births and a maternal mortality ratio of 400 per 100,000 live births.[4] The leading causes of morbidity and mortality are malaria, acute respiratory infections, diarrheal diseases and noncommunicable diseases.[5]

The Gambia endured a colonial regime for more than 400 years. At the time of its independence from Britain in 1965, there were only four Gambian physicians per 100,000 population, all in the capital, far from the majority of Gambians who continue to live in rural areas today. The only health care providers available to people in the countryside were traditional healers, known as marabous. Over the years since independence, a number of Gambian health professionals have been trained in developed countries, most choosing to remain there to practice, motivated by higher salaries and standards of living.[6,7]

Since 1996, by virtue of bilateral government accords, Cuban doctors (140 in 2011) have been the bulwark of the physician workforce in the country's public health system, particularly in the interior, supplemented by fewer physicians from Gambia and more short-term commitments by physicians from other nations.

In 1999, the country's first School of Medicine and Allied Health Sciences (SMAHS) was founded at the University of The Gambia, in collaboration with Cuba and WHO. The initiative was the result of priorities accorded by Gambia's government to three sectors for economic and social development: health, education and agriculture.[5] Other initiatives in these sectors included: construction of health centers, medical posts and hospitals in the interior;[8] and free primary education for girls (when low-income families have to pay for education, they tend to give priority to boys).[5]

SMAHS's program of study integrates elements from African universities (in partnership with the West African Health Organization, to which The Gambia belongs) with those drawn from Cuban medical education.[6] SMAHS has gradually acquired a good reputation in the region and has graduated professionals in various fields-Gambians as well as citizens of other countries.[6,7] The School and its graduates have undoubtedly contributed to improved management and functioning of the health system, but general practitioners, numbering 76 in 2011, the fifth graduating year,[9] are not sufficient to fill the gap in availability of medical personnel, especially in rural areas. The Gambia needs at least 150 physicians to guarantee the minimum primary health care coverage for a developing country, according to its total population, density (approximately 135 persons per $\mathrm{km}^{2}$ ) and distribution (74\% in rural areas).[10]

Considering this situation, in 2006, the governments of Cuba and The Gambia agreed to implement a new Community-Based Medical Training Programme (CBMP) in The Gambia,[11] modeled on the National Training Program for Comprehensive Community Physicians in Venezuela, created in collaboration with Cuba in 2005.[12,13]

Mounting international evidence suggests that students with rural backgrounds are more likely to practice in rural areas upon graduation, especially if their training takes place in sites close to future practice settings.[14] This was taken into consideration in developing the framework for CBMP, and thus an important difference between CBMP and traditional medical education programs is that training sites are located in the students' own communities.

CBMP's goal is to graduate community physicians with strong values of service, a solid scientific foundation and the necessary clinical competencies to provide comprehensive medical care at the primary level. They should graduate with the skills necessary to address community health problems through health promotion, disease prevention, treatment and rehabilitation activities with individuals, families and communities; and through preservation and improvement of the environment.[11]

The curriculum is taught by academically qualified Cuban physicians who are specialists in family medicine, the same physicians 
who provide clinical services to the communities where students are taught. From the start, CBMP has emphasized in-service learning to foster sensitivity to patients' needs and a humanistic approach to medical care, as well as the necessary scientific knowledge and skills.[11]

This article describes the activities and lessons learned during development and implementation of CBMP's premedical bridging course and startup of the full program in The Gambia.

\section{CBMP: STRATEGY AND IMPLEMENTATION}

Objective Organize and implement CBMP startup, including a premedical course, in the Republic of The Gambia.

Rationale Primary health care plays a key role in ensuring good population health, and is fundamental to improving the poor health indicators of nations such as The Gambia. In light of the scarcity of both human and material resources in the Gambian health system, particularly in rural communities, it becomes vitally important to develop health professionals trained to address the disease burdens and other health needs of the nation and to work in poor, remote communities in particular.[5] Yet, the slow pace of physician training in Gambian and sub-Saharan African universities, combined with health personnel emigration, has made it impossible to train and retain adequate numbers of doctors where they are most needed.[1]

Considering the objectives, structure and accessibility of the existing health care network (formed by four hospitals at the tertiary level, 38 health centers at the secondary level and 492 health posts at the primary level), as well as population morbidity patterns, training 150 physicians could fulfill the primary care mission in rural Gambian communities.[11] If CBMP's sustainability were guaranteed, with approximately 40 students per year entering a 6-year training program,[11] by 2017, full primary care coverage could be attained (including some graduates from SMAHS, and accounting for attrition from CBMP). In addition, in-service learning applies new knowledge and skills attained even before graduation.

Success of CBMP could exemplify an appropriate solution to building a sustainable physician workforce for rural areas of The Gambia and other countries where significant shortages exist.

Environment and population To organize the program strategically, a commission was formed with the Permanent Secretary of the President's Office, the Senior Deputy Ministers of Health and Education, and the head of the Cuban Medical Mission. This commission approved the following actions and commitments:

- The Cuban Medical Mission would provide faculty and Englishlanguage bibliography for core subjects; and would propose a list of supplementary literature to be furnished by the President's office.

- The President's Office would provide necessary equipment and supplies, such as generators, computers, video players, televisions, printers, photocopiers and office materials for each teaching unit, as well as the operating budget for the program, including equipment maintenance.

- The Ministry of Health would assume responsibility for maintenance of teaching sites and for student stipends and housing.
CBMP would be implemented in the four rural divisions (provinces) of the five in the country: Upper River, Western, North Bank and Central River.[5] The selection was based on degree of urbanization, distance between each division and the capital and access to transportation.

North Bank and Central River Divisions have general hospitals and Upper River and Western Divisions have health centers with inpatient care capabilities, laboratory services, minor surgery, birthing facilities, pediatric care, HIV counseling and urgent care.[15] Four locations in the interior were chosen as teaching sites, each with a history of total population coverage by Cuban medical teams; active social links between these physicians and the communities resulting in high acceptance by, and familiarity with, people living there; and significant engagement by community members and local authorities in health promotion activities developed with the Cuban teams since their arrival in 1999. These criteria were considered strengths to enhance likelihood of CBMP's success.[16]

Other factors considered favorable to prospects for success were:

- Presence of high schools in each rural division, with graduates who had aptitude for medical studies but did not pursue them for various reasons, mainly economic.

- Presence of SMAHS since 1999, with Cuban professors available to teach methodology and act as mentors and advisors to Cuban family medicine specialists who would teach in the new model of community physician training.

- The willingness of government and Gambian Ministries of Health and Education to work with the Cuban Medical Mission to implement a new joint program, based on their work together over the last decade.

- High motivation among Cuban physicians serving in The Gambia to develop CBMP.

Awareness raising An awareness-raising campaign was carried out by a delegation comprising the head of the Cuban Medical Mission, its education director, and two Cuban professors from SMAHS; plus the Health Ministry Deputy Director for Planning and the Ministry of Education's Head of Scholarships. The delegation visited all four divisions to describe methods for training community physicians and expected improvements in rural health care, and to stress the importance of local support for the endeavor's success.

The group met with local authorities, community leaders, division authorities and high school graduates who had decided against continuing their education because of financial constraints and instead were engaged in small business activities in very poor, rural commercial zones. Initial skepticism was addressed through ample explanation and discussion of program benefits.

As part of its preliminary analysis, the delegation also reviewed the scholarship system, academic requirements for university admission, the main subjects in which students experienced difficulties, the academic credit system, and the characteristics of the regional external exams administered in the final year of secondary school in the West African region.

Student selection process In February and March of 2007, students were selected for CBMP, chosen by the same delegation 
that conducted the awareness-raising campaign, with additional representatives from the Ministries of Health and Education from each of the divisions.

Applicants were required to be 25 years of age or younger and provide documentation of permanent residence in the division in which they applied. A rigorous selection process included assessment of high school academic records against a set of minimum requirements set by the commission, and an interview conducted by Cuban professors from the School of Medicine and Allied Health Sciences and division authorities from the Ministries of Health and Education. Interviewers explored candidates' command of written and spoken English, motivations for entering a career as a community physician, computer skills, general cultural knowledge and health status.

Faculty selection and methodological training Cuban family medicine specialists were identified through interviews, to determine those with the best English language capabilities who also had academic credentials, or previous teaching experience enabling them to continue towards accreditation, and who demonstrated interest and willingness to participate as CBMP professors.

From May to December 2007, three workshops were designed and conducted by Cuban professors from SMAHS to prepare CBMP instructors, as well as to foster continued development of language skills.

- The first concentrated on teaching methodologies. Key topics were pedagogical concepts, principles, methods and techniques in higher medical education, as well as use of information and communications technologies as tools in the teaching-learning process.

- The second provided training in teaching of the premedical course, including chemistry, physics, mathematics, biology, computer sciences, introduction to health sciences and Learning to Learn.

- The third workshop dealt with preparing comprehensive courses in morphophysiology[17] and other subjects covered in the first semester of CBMP's year one.

To assure continuing education for CBMP faculty, a Certificate of Higher Medical Education course was instituted, taught by a faculty of five professors, one with a doctorate in education and four with master's degrees in higher education (medical or general).[18]

Teaching sites and premedical studies Once the location with the best practical potential as a teaching site had been identified in each of the four divisions, it was thoroughly renovated to meet technical specifications for highly specialized classrooms. These accommodated 10-12 students each and were located in or near hospitals and health centers.

In each of the four divisions, one classroom was set up with printed textbooks, supplementary digital materials and the technology necessary to support the teaching process. Required media were distributed equitably among the four teaching locations: a total of 44 computers with internet access were installed, and each site was allocated: a television, combined DVD and video cassette player, printers, photocopier, and a generator with sufficient capacity to support the teaching-learning process during power failures.
The curriculum design included a premedical bridging course to bring all students up to a common level in basic sciences and general knowledge, due to the variance in standards among schools in the Gambian educational system.[19]

\section{RESULTS}

A total of 45 students were selected to enter CBMP (34 men and 11 women), all from poor towns or localities, the majority children of farmers or small merchants. They lacked financial means to pursue higher education, but were considered to have sufficient academic skills to become physicians capable of addressing the most important health problems and of promoting healthy lifestyles and behaviors in their communities.

The premedical course was taught in the first semester of the 2007-2008 academic year. Academic retention was good and key reasons for attrition had to do with the difficult socioeconomic context in which the program was carried out (four students dropped out, primarily to find jobs).[20]

CBMP's first year was offered in 2008-2009, with a curriculum that included comprehensive courses in morphophysiology, community health and medical informatics. In these cases, the materials were translated from the Spanish originals by CBMP faculty, with assistance from a translator and other members of the Cuban Medical Mission in The Gambia.

Representative of the various parties involved-students, Cuban teachers and local community authorities where CBMP was implemented-have expressed satisfaction with the program thus far.[21]

Lessons learned The combined efforts of the Cuban Medical Mission and the Gambian government health and educational institutions were critical to implementation of the premedical bridging course and CBMP's first year.

Skepticism on the part of local authorities, community leaders, regional authorities and students themselves was addressed through face-to-face contacts that transparently and directly conveyed the concepts and feasibility of CBMP.

The country's low level of economic development was not an insurmountable obstacle to implementing CBMP.

CBMP has the potential to make Cuba's contribution to Gambian population health more comprehensive by continuing to help build local human resources for health, especially those committed to practice in the rural communities from which they come.

The fact that Cuban doctors providing health care also train local physicians where they practice may promote a stronger sense of investment and commitment in both teachers and students, a subject for further research.

Final considerations The ultimate success of CBMP will depend on the quality of its graduates and their commitment to serve in the public health system in remote and poor communities of The Gambia. Followup studies should be conducted to monitor this process, as the experience may be an important one for other developing countries, particularly in Africa. $1 /$ - 


\section{REFERENCES}

1. The World Health Report 2006: Working together for health. Geneva: WHO Press; 2006.

2. AEGiS [Internet]. UNAIDS Epidemiological Fact Sheets. Gambia, Facts and Figures. 1990-2001. Geneva: UNAIDS; c2002 [cited 2010 Apr 18]. Available from: http://www.aegis.org/files/unaids/ june2000/Gambia_en.pdf

3. Human Development Index (HDI) - 2011 Rankings [Internet]. New York: UNDP; [cited $2011 \mathrm{Dec}$ 09]; [about 1 screen]. Available from: http://hdr .undp.org/en/statistics/.

4. World Health Statistics 2011 [Internet]. Geneva: World Health Organization; 2011 [cited 2011 Nov 1]. 170 p. Available from: http://www.who int/gho/publications/world_health_statistics/EN WHS2011_Full.pdf

5. Second Generation, WHO Country Cooperation Strategy, 2008-2013, Gambia. [Internet]. Brazzaville (CG): WHO Regional Office for Africa; 2009 [cited 2011 Dec 9]. 40 p. Available from: http://www.afro.who .int/index.php?option=com_docman\&task=doc _download\&gid=3325\&ltemid $=2111$

6. Reed GA. University of The Gambia: Medicine Seemed the Place to Start [Internet]. MEDICC Rev. 2005 Aug-Sep [cited 2010 Apr 10]; [about 2 screens]. Available from: http://www.medicc. org/publications/medicc_review/0305/pages/ international_cooperation_report.html

7. Menéndez Cabezas A. Experience of Cuban Faculty in Establishing a Medical School in the Republic of The Gambia [Internet]. MEDICC Rev. 2005 Aug-Sep [cited 2010 Apr 10];7(8):1922. Available from: http://www.medicc.org/ publications/medicc_review/0805/cuban -medical-literature.html

8. Gambia Country Health Profile 2003 [Internet]. Geneva: World Health Organization; 2006 [cited 2011 Nov 5]. 54 p. Available from: http://www.afro. who.int/index.php?option=com docman\&task $=$ doc download\&gid $=2836$

9. Faal M. 14 Gambian medical doctors sworn in [Internet]. Daily Observer. 2011 Dec 01 [cited 2011 Dec 9]. Available from: http://observer.gm/ africa/gambia/article/14-gambian-medical-do ctors-sworn-inl

10. Dreesch N, Dolea C, Dal Poz MR, Goubarev A, Adams $\mathrm{O}$, Aregawi $\mathrm{M}$, et al. An approach to estimating human resource requirements to achieve the Millennium Development Goals [Internet] Health Policy Plan. 2005 Sep [cited 2011 Nov 1];20(5):267-76. Available from:http://heapol .oxfordjournals.org/content/20/5/267.full.pdf
11. National Academic Coordinating Committee for the Community-Based Medical Programme. A new model for the formation of Medical General Practitioners in the Community. Banjul (The Gambia): Cuban Medical Brigade; 2007.

12. Borroto Cruz ER, Salas Perea RS. National Training Program for Comprehensive Community Physicians, Venezuela [Internet]. MEDICC Rev. 2008 Fall [cited 2010 Apr 10];10(4):35-42. Available from:http://www.medicc.org/mediccreview/ index. php? issue $=1$ \&id=9\&a=va

13. Borroto Cruz ER, Salas Perea RS, Díaz Rojas PA. Un nuevo modelo formativo de médicos en la Universidad Barrio Adentro, República Bolivariana de Venezuela. [Internet]. Educ Med Super. 2010 [cited 2010 Apr 10];24(1):111-35. Available from: http://bvs.sld.cu/revistas/ems/ vol 241 10/ems13110.htm. Spanish.

14. de $\bar{V}$ ries $\bar{E}$, Reid S. Do South African medical students of rural origin return to rural practice? S Afr Med J. 2003 Oct;93(10):789-93.

15. Bansang Hospital Appeal [Internet]. The Hospitals in The Gambia. The Gambia; c2010 [updated 2011 Jul 3; cited 2010 Apr 10]. Available from: http://www.bansanghospitalappeal.com/ban sang/index.htm

16. Jallow A. Cuba Committed to Strengthening Support to Nation's Health Sector [Internet]. Gambia News-Daily Observer. Banjul, Gambia; c2011 [updated 2012 Jan; cited 2011 Dec 1]. Available from: http://observer.gm/afrca/gambia/ article/cuba-committed-to-strengthening-support-to-gambias-health-sector

17. Morales Suárez IR, Fernández Sacasas JA, Durán García F. Cuban Medical Education: Aiming for the Six-Star Doctor [Internet]. MEDICC Rev. 2008 Fall [cited $2010 \mathrm{Apr}$ 10];10(4):5-9. Available from: http://www.medicc.org/medicc review/index. php?issue $=1 \& i d=3 \& a=v a$

18. Infomed [Internet]. Inician superación pedagógica médicos cubanos en Gambia. Havana: Ministry of Public Health (CU); c2009 [updated 2009 Mar 11; cited 2010 Apr 10]; [about 1 screen]. Available from: http://www.sld.cu/ser vicios/temas. php?idv=24287\&idl=14\&page=12. Spanish.

19. Farjas Bonet A. La escolarización en Gambia [Internet]. Revista Española de Educación Comparada. 2002 [cited 2010 Apr 10];8:227-59. Available from: http://www.uned.es/reec/pdfs/08 $-2002 / 12$ farjas.pdf. Spanish.

20. del Rosario Marrero O, Sosa Palacios O, Pérez Suárez GY. Valoración del proceso docente-edu- cativo del curso pre-médico del Nuevo Programa de Formación de Médicos de la Comunidad. Rev Méd Electrón. Cuba. Forthcoming 2012. Spanish.

21. CubaMinrex [Internet]. Realizan acto de inicio del segundo año del Nuevo Programa de Formación de Médicos en la Comunidad en cuatro centros docentes de Gambia. Havana: Ministry of Foreign Affaires; c2009 [updated 2009 Nov 9; cited 2010 Apr 10]; [about 1 screen]. Available from: http:// www.cubaminrex.cu/Cooperacion/2009/1119. html. Spanish.

\section{THE AUTHORS}

José A. Chávez Viamontes (Corresponding author: jchavez@finlay.cmw.sld.cu),physician specializing in embryology with a master's degree in comprehensive pediatric care.

Associate professor and vice-dean of research, Faculty of Medical Sciences, Medical University of Camagüey, Cuba.

Lázaro V. Suárez Navarro, physician specializing in family medicine, Matanzas, Cuba.

Odalis del Rosario Marrero, physician specializing in family medicine with a master's degree in higher education. Assistant professor, Medical University of Matanzas, Cuba.

Suiberto Hechavarría Toledo, internist with a master's degree in higher medical education. Associate professor, Comandante Manuel Fajardo Medical Faculty, Havana, Cuba.

Judith Quiñones Hernández, physician specializing in pharmacology with a master's degree in emergency medicine. Assistant professor of pharmacology, Medical University of Camagüey, Cuba.

Submitted: June 9, 2010

Approved for publication: December 12, 2011 Disclosures: None 